\title{
高炉スラグおよびフライアッシュを用いた 混合セメントの複合水和発熱モデル
}

\author{
岸 利治 $^{1} \cdot$ 前川宏一 ${ }^{2}$ \\ ${ }^{1}$ 正会員 博士: ( T学) 東京大学講師 工学系研究科社会基盤工学専攻（テ113 東京都文京区本郷 7-3-1） \\ “正会員 L博 東京大学教授 工学系研究科社会基盤工学専攻（テ113 東京都文京区本郷 7-3-1）
}

\begin{abstract}
マスコンクリート構造物の温度応力解析において効率的な材料設計を行うためには, 種々のポルトラン ドセメントのみならず，高炬スラグやフライアッシュを含めた様々な粉体の組み合わせに対応可能なセメ ントの水和発熱モデルを与えることが求められる。本研究は，七メントの水和反応を構成鈗物ごとに記述 する水和発熱モデルに，高炉スラグおよびフライアッシュに対応する要素を組み入れた混合セメントの水 和発熱モデルを提案するものである．各鉱物反応の発熱速度は基準発熱速度と温度活性の 2 つの材料関数 により表現され，クリンカー鉱物および混和材間の相互依存性は要因毎に考慮されている. 構築した水和 発熱モデルは，断熱温度上昇値及び擬似断熱試験体の温度計測結果によって検証された。
\end{abstract}

Key Words : clinker minerals, blust-furnace slag, fly ash, hydration heat, multi-component model

\section{1.はじめに}

現在，コンクリート用の混和材として，高炉スラグ，フ ライアッシュ, 石灰石微粉末, 膨張材などの多くの粉体が 使用されている. 特に, マスコンクリート構造物用の混和 材としては, 結合材としても機能する高炬スラグ及びフラ イアッシュか㳂く用いられている. 低発熱型のポルトラン ドセメントを含めて, 温度ひび割れ対策として使用される 粉体は複数であり, 粉体の置換割合まで考虑すると, 温度 ひび割れ照査において検討の対照となる組み合わせは広 範にわたる．したがって，水和発熱モデルがマスコンクリ 一ト構造物の温度解析に資するためには, 混和材を含めた 系をも対象とすることが不可欠である. 特に, 自己充填性 ハイパフォーマンスコンクリードでは, 自己充填性能を 実現するために一定量以上の単位粉体量を確保する必要 があり，その温度ひび割れ照査においては，実質上，使用 粉体の種類及び置換割合の検討を行うこととなる ${ }^{2)}$. 著者 等はこれまでに，ポルトランドセメントを対象とした複合 水和発熱モデルを提案している3，4). 複合水和発熱モデ ルにおいては，セメント中の反応をクリンカー鉱物毎に記 述しており，鉱物反応間の相互依存性は别途考慮している. すなわち, 結合材内の反応を適切な反応単位毎に記述する 構成になっており，混和材に相当する新たな要素の組込み と, 反応間の相互依存性の考慮が合理的に取り扱える形式 となっている. 本研究の目的は, ポルトランドセメントの 複合水和発熱モデルに高炉スラグおよびフライアッシュ
の要素を組込み, モデル全体の混合セメントへの適用範囲 の拡張を図るものである.

各種の混和材が添加された混合セメントでは, 全体を単 一の反応系として取り扱うことは必ずしも合理的ではな い. 全体を単一の反応系としてマクロにモデル化する場合 には, 反応程度を表わす指標として水和率や積算発熱量な どを全体系に対して定義することになる。しかし，温度依 存性が異なる複数の鉱物反応の組み合わせにおいては, 温 度履歴が異なれば, 系全体の反応程度を表わす指標に対し て, 各反応毎の反応率は一意には定まらない. 混合セメン トにおいては, ポルトランドセメント単体の場合に比べて 反応間の相互依存性が一層複雑であるために, 系全体とし ての反応程度を一つの指標のみで定義することの妥当性 は保証されていないのである. 仮に, 同一系内で進行する 反応間の相互依存性が複雑であるにもかかわらず, 反応系 全体を単一として扱うとすれば, 見掛け上, 複雑なモデル 化が必要であると考えられる。 そこで, 複合水和発熱モデ ルでは, 広範なポルトランドセメントの種類および任意の 温度履歴に対応するために, クリンカー鉱物毎に反応を記 述し，その上で鉣物反応間の相互依存性も考虑している. 適切な反応単位毎に発熱速度を記述し, 反応間の相互依存 性を要因毎に評価する複合水和発熱モデルの構成 ${ }^{4)}$ は, セ メントと混和材間の相互依存性が複雑な混合セメントに おいては，一層の合理性を有するものと言える.

実際，混合セメントにおける高炉スラグおよびフライア ッシュの反応は, ポルトランドセメント中のエーライトお 
よびビーライトより生成される水酸化カルシウムに依存 している ${ }^{5 !}$. 水酸化カルシウムの供給が十分であれば混和 材の反応は進行し, 逆に供給量が不十分であれば反応は抑 制されることになる。すなわち，混和材の反応発熱過程を 適切に表わすためには，エーライトおよびビーライトから の水酸化カルシウムの生成量と混和材による消費量を定 量的且つ時系列に算定する必要がある。このように，任意 の温度履歴に対応し反応相互の依存性を適切に評価する ためには, 混合セメント中に拀ける反応群を反応単位毎に 区分して記述することが不可久である，言い換えれば，七 メント中のクリンカー鉱物および各混和材ごとに水和発 熱反応を記述するアプローチは, 種々のセメント種類, 混 和材の置換率, 温度履歴に対応して混合セメントの水和反 応過程を適切に表現し得るものといえる。

そこで本研究では, 高炬スラグ及びフライアッシュの発 熱反応過程をセメント反応により生成される水酸化カル シウム量を用いて記述すると共に, フライアッシュによる セメント及び高炬スラグに対する反応遅延効果について も考慮することとした，これらは，混和材とポルトランド セメント間に起こる水和発熱反応に関する相互依存性で あり，複合水和発熱モデルによって合理的に取り扱うこと が可能となるのである.

\section{2. 混合セメントの水和発熱過程のモデル化}

\section{（1）複合水和発熱モデルの基本概念と一般式 ${ }^{4)}$}

複合水和発熱モデルでは，セメントの反応を反応の基本 単位と考えられるクリンカー鉱物ごとに分解して取り扱 っている4).すなわち, エーライト $(\mathrm{C} 3 \mathrm{~S})$ ，ビーライト

$\left(\mathrm{C}_{2} \mathrm{~S}\right)$ ，アルミネート相 $\left(\mathrm{C}_{3} \mathrm{~A}\right)$ ，フェライト相 $\left(\mathrm{C}_{4} \mathrm{AF}\right)$ の各鉱物を反応単位として取り扱っている. 複合水和発熱 モデルの対象範囲を混合セメントにまで拡張するに当り， 高炉スラグ及びフライアッシュをそれぞれ反応の基本単 位として捉え, 複合水和発熱モデルに構成要素として追加, 組み入れることとした. 高炉スラグおよびフライアッシュ を単一の反応単位として取り扱い，それぞれの反応をセメ ントの場合のように細分化していないのは，両者とも常温 で反応に関与するのはガラス相であり，これらは，ほほ均 質な材料と見なすことができるので, 単一な反応単位とし て取り扱っても差し支えないと判断したことによる.ただ し，高炉スラグの反応は，石膏の存在により影響を受ける5 が，現段階では考虑していない. したがって，混合セメ ント総体の発熱速度は次式で表現される。

$$
\begin{aligned}
\bar{H}= & \sum p_{i} \bar{H}_{i} \\
= & p_{C_{3 A} A}\left(\bar{H}_{C_{3 A E T}}+\bar{H}_{C_{3 A}}\right)+p_{C_{4 A F}}\left(\bar{H}_{C_{4} A F E T}+\bar{H}_{C_{4} A F}\right)(1) \\
& +p_{C_{3} S} \bar{H}_{C_{3} S}+p_{C_{2} S} \bar{H}_{C_{2} S}+p_{S G} \bar{H}_{S G}+p_{F A} \bar{H}_{F A} \\
\text { ここで, } i \text { は各クリンカー鉱物, 高炉スラグ( } \mathrm{SG}) \text { もしくは } &
\end{aligned}
$$

フライアッシュ(FA)を表わす． $\bar{H}$ は混合セメント総体の 水和発熱速度, $\bar{H}_{i}$ は鉱物 $i$ の単位重量当りの発熱速度, $p_{i}$ は鉱物 $i$ の組成重量比である. $\bar{H}_{C_{3} A E T}$ 及び $\bar{H}_{C_{4} A F E T}$ は, $\mathrm{C}_{3} \mathrm{~A}$ 及び $\mathrm{C}_{4} \mathrm{AF}$ と石高の反応によるエトリンガイトの生成 に伴う発熱速度を表わす。

高炉スラグ及びフライアッシュの発熱速度の記述も，ク リンカー鉱物と同様に温度一定条件下での基準発熱速度 と温度活性の 2 つの材料特性値を用いて定式化する ${ }^{4)}$ ，6). ただし，高炉スラグ及びフライアッシュの反㐫は，セメン トから生成される水酸化カルシウムの刺激を必要とし, 且 つ反応の進行に伴って水酸化カルシウムを消費するもの と考え, 水酸化カルシウム量に対する反応依存性を表現す る係数 $\lambda$ を新たに導入する. 3 成分系混合セメントの水和 発熱過程をモデル化するためには, 各反応要素の相互依存 性を適切に表現する必要がある. 本研究においては, 相互 依存要因として, 水和に要する自由水を各鉱物が共有する こと, 高炉スラグとフライアッシュの反忘にエーライトお よびビーライトより生成される水酸化カルシウムが関係 すること,フライアッシュおよび有機混和剂がポルトラン ドセメント及びスラグの反応に対して遅延効果があるこ とを考虑するものとした．したがって，反応間の相互依存 性を考虑した各要素の水和発熱速度は次式で一般的に表 わされる。

$$
\begin{gathered}
\bar{H}_{i}=\gamma \cdot \beta_{i} \cdot \lambda \cdot \mu \cdot s_{i} \cdot \bar{H}_{i, T_{0}}\left(Q_{i}\right) \exp \left\{-\frac{E_{i}}{R}\left(\frac{1}{T}-\frac{1}{T_{0}}\right)\right\} \\
\bar{Q}_{i} \equiv \int \bar{H}_{i} d t
\end{gathered}
$$

ここで, $E_{i}$ は鉱物 $i$ の活性化エネルギ一, $R$ は気体定数, $\bar{H}_{i, T_{0}}$ は基準温度 $T_{0}$ における鉱物 $i$ の基準発熱速度であ り, 積算発熱量 $\bar{Q}$ の関数, $\gamma$ は初期水和発熱過程におけ るフライアッシュ及び有機混和剤による遅延効果を表わ す係数， $\beta_{i}$ は自由水 (析出空間) の減少による発熱速度 の低減を表わす係数， $\lambda$ は液相中の水酸化カルシウム量に 依存した高炬スラグ及びフライアッシュの発熱速度の変 化を表わす係数， $\mu$ はポルトランドセメントの鉱物組成の 相違による発熱速度の变化を表わす係数, $s_{i}$ は粉末度の相 違による基隼発熱速度の变化を表わす係数である. ただし， $\gamma, \beta_{i}, \lambda, \mu$ の各係数は, それぞれ他の要因の影響に よる速度变化がない状態に対する変化率を与える係数と 仮定し, 複数の係数が 1 末満の低減率を与える場合には, 最も小さい係数を以って発熱速度の低減率が与えられる ものとする.なお, 既往の複合水和発熱モデル ${ }^{4}$ に, 新た に追加されたパラメータは 及 及び $s_{i}$ である。また, $-E_{i} / R$ をもって温度活性と定義する。

\section{（2）構成要素の基淮発熱速度}

各クリンカー鈗物及び混和材の反応の材料特性值とし て設定した基準発熱速度 $\bar{H}_{i, T_{0}}$ を図一1 に示す. クリンカー 

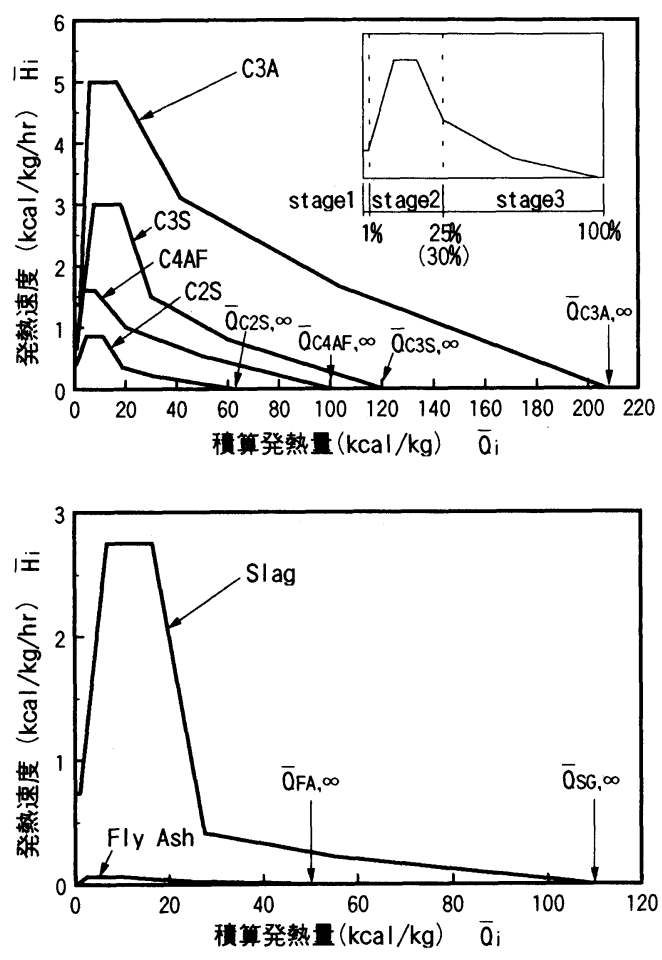

図-1 各鉱物反応に設定した基準発熱速度

鉱物の基準発熱速度は，普通ポルトランドセメントにおけ る発熱速度として設定しており, 基準温度 $T_{0}$ は攝氏 20 度 とした. 図一1 に示した基準発熱速度は，基本的に既往の研 究4)によって決定されたものであるが, 水和発熱過程区分 などについて若干の修正を行っている. すなわち, $\mathrm{C}_{3} \mathrm{~S}$ 及 び $\mathrm{C}_{2} \mathrm{~S}$ の水和発熱過程に対して, 便宜上設定している領域 の分割について, stage1 と stage2 の境界を最終発熱量の 3\%から 1\%に修正し, stage2 と stage3 の境界を 20\%か ら， C $3 \mathrm{~S}$ は25\%に，C2S は30\%にそれぞれ修正した. 本 研究で新たに設定した高炉スラグ及びフライアッシュの 基準発熱速度は, 水和に必要な水が十分に練り混ぜ水とし て存在し, 尚且つ, 反応の刺激剂となる水酸化カルシウム がポルトランドセメントから十分に供給される場合にお ける発熱速度とした. フライアッシュのポゾラン反応の先 駆けとなるフライアッシュ中のガラス相と $\mathrm{Ca}^{2+}$ イオンと の反応は一般に遅く, 常温では 1 - 3 日より生起する5) と言われており, 基準発熱量を最終発熱量で除した反応速 度は，高炉スラグに比べフライアッシュの場合には著しく 小さな値を設定している.

通常, 混和材は単体では水和反応を起こさないため, 混 和材単体の水和発熱速度を実験的に同定することは困難 である.また，試薬を加えた際に計測される発熱速度は， セメントと共存する混合セメント中の高炉スラグもしく はフライアッシュの発熱速度とは異なることが知られて
いる.このことは, 添加する試薬の種類に応じて, 混和材 の反応性が異なることからもうかがえる ${ }^{5 !}$ ．そこで, 高炉 スラグ及びフライアッシュの基準発熱速度の設定は, 後述 する鈴木の行った系統的な断熱温度上.昇試験結果 ${ }^{7}$ に対 する解析を通して行った。この際に設定した混和材の単位 重量当りの発熱量 (最終発熱量 $\bar{Q}_{i \infty \infty}$ ) については, 解析と 実験結果との整合と合わせて定性的な知見からも推定す ることができる，高炉スラグの発熱性状としては，普通ポ ルトランドセメントに混入した場合でも，低い置換率にお いては断熱温度上昇量の終局值はほとんど変わらないこ とが知られている。一方，中庸熱ボルトランドセメントを 高炬スラグによって置換した場合には, 終局值が上昇して しまう ${ }^{8)}$.このことより，セメント中で反志する高炉スラ グの単位重量当りの発熱量は, 普通ポルトランドセメント と同程度であり, 中庸熱ポルトランドセメントよりは大き いものと考えられる. そこで, 本解析においては, 高炉ス ラグの単位重量当りの発熱量を $110 \mathrm{kcal} / \mathrm{kg}$ と仮定した.

フライアッシュの場合には, スラグとは異なり, 発熱量に 関する定量的な情報が少ない. 断熱温度上昇試験の測定期 間内に扔て，フライアッシュの反応か完全に終了してい るかは不明であり, 単位量当りの発熱量, 言い換えれば基 準発熱速度における最終発熱量の設定值は暫定的な值 $(50 \mathrm{kcal} / \mathrm{kg})$ を本研究では設定している.

提案するモデルを様々な粉体に適用するためには, 粉体 粒子の粉末度にも対応する必要がある。一般に, 同一の粉 体であれば微粉砕されたものほど, 見掛け上，単位量当り の反応速度が大きくなる. 特に, 早強セメントでは普通ポ ルトランドセメントに対して, 鉱物組成を変化させると共 に, 粉末度も高くしている. また, 高炉スラグも種々の粉 末度のものか製品化されている。 すなわち，モデルにおい て仮定した材料特性値は, 材料特性值を同定するために採 用した断熱温度上昇試験に用いられた材料の粉末度に対 応する值といえる。そして，反応における粉末度の影響は， 均質な粉体に扔いては水などの反応対象との接触機会の 大小にのみ表れると考え, 本モデルでは粉末度に応じて基 準発熱速度のみを变化させることとした. 粉体の粉末度を 表わす指標にはブレーン比表面積を用い, 粉末度の相違に よる基準発熱速度の変化率 $s_{i}$ を次式により表現する.

$$
s_{i}=S_{i} / S_{i 0}
$$

ここで, $S_{i}$ は鉱物 $i$ のブレーン比表面積 $\left(\mathrm{cm}^{2} / \mathrm{g}\right), S_{i 0}$ は鉱 物 $i$ の基準ブレーン比表面積である. ポルトランドセメン ト, 高炬スラグ, フライアッシュの基準ブレーン比表面積 は, 材料関数の同定に用いた断熱温度上昇試験 $\left.{ }^{6} .7\right)$ に使用 された粉体のブレーン比表面積とし，それぞれ 3380, 4330， $3280\left(\mathrm{~cm}^{2} / \mathrm{g}\right)$ とする. ただし，C3S，C2S 及び高炉スラグ の stage2 においては, 今回は粉末度の影響は考虑してい ない $\left(s_{i}=1\right)$. 


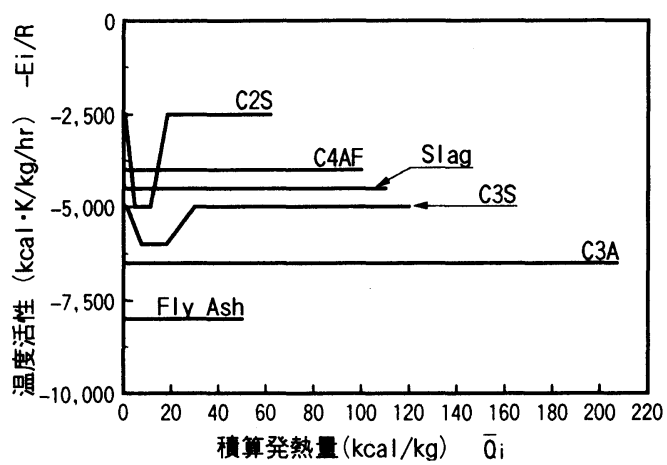

図-2 各鉱物反応に設定した温度活性

\section{（3）各鉱物反応の温度活性}

本研究では，各鉣物毎の温度依存性の表現には，鈴木ら の手法 ${ }^{61}$ を参考に，鉱物の積算発熱量に対する温度活性を 設定している.ただし，本研究では，セメント総体として は見掛け上, 複雑に変化する温度活性 ${ }^{6)}$ も，固有の温度活 性を持った複数の反応の重枚合わせとして合理的に説明 できるとするスタンスをとっている. そこで, 鈴木らの同 定したセメント総体の温度活性值を参考に, 各クリンカー 鉱物の温度活性值には, $\mathrm{C}_{3} \mathrm{~A}>\mathrm{C}_{3} \mathrm{~S}>\mathrm{C}_{4} \mathrm{AF}>\mathrm{C}_{2} \mathrm{~S}$ の順に, $-6500(\mathrm{kcal} \cdot \mathrm{K} / \mathrm{kg} / \mathrm{hr})$ から-2500 までの一定值を割り当て ている.モデルにおいて設定した各鉱物の温度活性を図一2 に示す. $\mathrm{C}_{3} \mathrm{~S}$ および $\mathrm{C}_{2} \mathrm{~S}$ の水和発熱過程における stage2 では，イオンの溶出と連成して進行する析出反心よりも, stage1 において既に溶出し過飽和状態にあるイオンから の析出反応の影響が卓越していると考え，他の水和発熱反 応区分における温度活性值とは異なる值を設定している.

高炉スラグの温度活性值としては，鈴木の検討において 同定された高炉スラグ 40\%置換の配合の温度活性值 ${ }^{7)}$ が, 普通ポルトランドセメント単体のものよりも相対的に若 干小さいことから, クリンカー中の主要鉱物である $\mathrm{C}_{3} \mathrm{~S}$ の stage3 に設定した值よりも幾分小さい-4500を与えた. な お, 解析を通した検討の結果, 高炉スラグの stage2 と stage3 の温度活性值としては，同一の值を仮定した. 一方, フライアッシュの反応に伴う発熱量は母材セメントの発 熱量に対して微少であり, 両反応間の相互作用も大きいこ とから, 混合セメント総体の温度活性值からフライアッシ ユの温度活性值を推定することは困難である. そこで, フ ライアッシュの温度活性值は, 解析を通して妥当と考えら れる值を設定した. この際，常温におけるフライアッシュ の反応速度がポルトランドセメントに比べて極めて遅い にもかかわらず, フライアッシュからの発熱を無視すると 母材セメントからの発熱量だけでは混合セメントの断熱 温度上昇量を再現することはできなかった. そこで, 高温 履歴においてはフライアッシュの反応は顕著に促進され
るものと考え，現在のところ暫定的に-8000 という比較的 大きな温度活性値を与えている。

\section{（4）エトリンガイトの生成反応モデル}

従来より，断熱温度上昇量の終局値は，打設温度の影響 を受けることが知られており，鈴木らの行った実験におい ても, 概して打設温度か泜い場合の方か終局温度上昇量が 大きくなっている ${ }^{9)}$. しかし，著者等の提案しているポル トランドセメントの複合水和発熱モデルでは, 打設温度が 低い場合ほど終局温度上昇が大きくなる現象を再現する ことができず, 必ず打設温度の高い方か終局温度も高くな る結果となった。 セメント硬化体の微細構造は, 温度履歴 に応じて変化するとの指摘があり ${ }^{10)}$ ，打設温度が低い場 合の終局温度上昇量が高くなる理由の一つには，拡散抵抗 となる水和生成物の組織構造が, 温度履歴に応じて变化す ることが考えられる．また，断熱温度上昇試験においては， セメントの水和か始まる練混ぜ開始から, 温度言測の開始 までには听要の時間を要するために, 打設温度の上昇とし て取り込まれる水和開始以降の発熱量が, 系の温度に応じ て異なることも想像に難くない. 鈴木による精密な断熱温 度上昇試験結果の打設直後の温度履歴6) を詳細に観察す ると, 打設温度が $30^{\circ} \mathrm{C}$ 場合には, 計測開始直後にほとん と温度が上昇しない期間が認められるのに対し，打設温度 が $10^{\circ} \mathrm{C}$ 場合には, 計測開始直後から微少な温度上昇が認 められ，その後に温度上昇が停滞する期間が現れる。この ように, 打設温度に応じて断熱温度上昇曲線の初期の挙動 か溦妙に異なるのは, 反応の温度依存性を反映して, 計測 開始以前の発熱量が初期温度に応じて異なるためと考え られる.つまり，打設温度が高い場合には，注水直後の第 1発熱ピーク11)に相当する初期反応の大部分か打設まで の間に終了するために, 初期反応に伴う発熱のほとんどは 打設温度の上昇として表れるに対して, 打設温度が低い場 合には, 第 1 発熱ピークに相当する発熱の一部か計測開始 直後の微少な温度上昇として現れるものと考えられる.し たがって, 温度履歴の相違によって細孔組織構造が変化す ることに加えて, 断熱温度上昇量の一部として計測される 初期の発熱量が初期温度に応じて異なることも, 打設温度 が高いほど終局温度上昇量か泜くなる一因と考えた。

そこで, 打設温度の相違に応じて温度上昇量を適切に再 現するためには, 練り混ぜ開始直後より活発な発熱をもた らすエトリンガイトの生成発熱反応を的確にモデル化し なければならない. 著者等か提案しているポルトランドセ メントの水和発熱モデルにおいては，これまでもエトリン ガイトの生成に伴う発熱モデルを組み入れてきたが, 基準 発熱速度の設定が不適切であったために練り混ぜ開始か ら打設までの発熱過程を適切に評価していなかった。 そこ で, モデルにおいて設定しているエトリンガイトの基準発 熱速度を修正し, さらに, 注水から温度計測開始までを約 


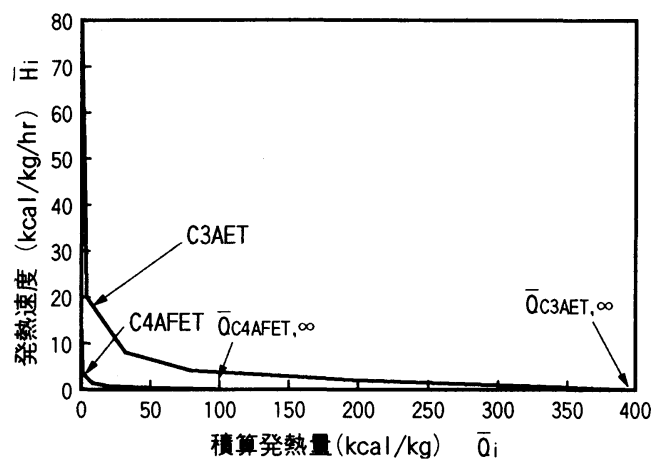

図-3 エトリンガイトの生成反応に設定した基準発熱速度

20 分 $(0.015$ 日) と仮定した上で，この間の発熱量および 経過時間は解析結果に含めないこととした，これは，本研 究において解析の原点としている計測開始時の打設温度 には, 既に練混ぜ開始以降の発熱量の一部か内包されてい るものと考えたことによる.すすなわち, 本研究で行ってい る全ての解析では，プログラムの開始から0.015 日までの 発熱量は温度上昇量には算入せず, 断熱温度上昇の原点を 水和開始 0.015 日後にとることとしている. 修正した $\mathrm{C}_{3} \mathrm{~A}$, $\mathrm{C}_{4} \mathrm{AF}$ と二水石高によるエトリンガイトの生成反応に伴う 基準発熱速度を図-3に示す. $\bar{H}_{C_{3 A}}$ および $\bar{H}_{C A A F}$ で表わさ れる間隙質の水和発熱は，未反応石膏の消失による エトリンガイトの生成反応の終了と同時に直ちに開 始するとモデル化している。

\section{(5)構成要素間の反応相互依存性の評価}

本研究では, 各鉱物単位の反応を個々に記述しているた め, 各反応間の相互依存性は別途考虑する必要がある. ポ ルトランドセメントの複合水和発熱モデルでは, 鉱物の反 応が相互に影響を及ぼし合う要因として，まず水和に要す る水を取り上げ, 且つ水和生成物の析出空間である自由水 を各構成鉱物が共有することを考虑している ${ }^{4)}$.さらに, 鉱物組成の相違に応じて $\mathrm{C}_{3} \mathrm{~S}$ 及び $\mathrm{C}_{2} \mathrm{~S}$ の拡散律速過程 (stage3)での発熱速度か湾化すると考え, モデル化してい る. また, 各反応の発熱量に応じて変化する系全体の温度 も，それぞれの水和発熱過程を支配する共通環境として, 相互依存性に関与する要因となっている.

本研究において, 複合水和発熱モデルを混合セメントに 拡張するに当り, ポルトランドセメントおよび高炬スラグ, フライアッシュ間の相互依存性を新たに考慮する必要が ある. 高炉スラグとフライアッシュでは, 反応形態がやや 異なり, 反応性は大きく異なるが, いずれも単独では水と 継続的な反応は起こさず, $\mathrm{Ca}(\mathrm{OH})_{2}$ の存在下において水硬 性を発揮する。 そして, 混合セメント中においては, $\mathrm{Ca}(\mathrm{OH})_{2}$ は $\mathrm{C}_{3} \mathrm{~S}$ 及び $\mathrm{C}_{2} \mathrm{~S}$ の水和反応により生成される.
すなわち, 高炬スラグおよびフライアッシュの反応はポル トランドセメントの反忘に依存しており，3成分系の混合 セメントにおいては高炉スラグとフライアッシュは $\mathrm{Ca}(\mathrm{OH})_{2}$ を共有する関係にある. したがって, 混合セメン ト中における各構成鉣物の反応過程を混和材まで含めて 適切に評価するためには, $\mathrm{Ca}(\mathrm{OH})$ 2によって媒介される相 互依存性の評価をモデルに導入する必要がある。 また，フ ライアッシュによってもたらされるポルトランドセメン ト及び高炉スラグに対する遅延効果もモデルにおいて考 慮しなければならない。

\section{a) 自由水の減少による水和発熱速度の低减}

自由水量は, 水和の継続に対して供給可能な水量である と同時に水和生成物の析出可能空間量をも意味している. 複合水和発熱モデルでは基準発熱速度を, 粒子周辺に自由 水が十分に存在する場合の水和発熱速度として想定して いる. しかし，水セメント比が低い配合においては，水和 の進行と共に粒子近傍に十分水が存在するとの仮定は成 り立たなくなるため, 設定している基準発熱速度に対して 実際の反応速度は低下する. 複合水和発熱モデルでは, 自 由水の減少による発熱速度の低减は, 粒子中の反応面と自 由水との接触機会の減少により生じるものとし, 発熱速度 の減少程度を表わす係数 $\beta_{i}$ を自由水量及び内部生成層厚 を用いて簡略に定式化している4 . 採用している関数形は, 0から 1 の值をとるものであり, 自由水が十分存在し, か つ水和生成層か薄い段階ではほとんど低減がかからず, 逆 に系に残存する自由水量が減少し，かつ未反応部分か㴟い 生成層に覆われた段階では, 著しい低减がかかるものとな っている. 本研究では, 粉体の粉末度を取り扱うことにし たのに伴い, 粉末度の相違による基準発熱速度の変化を表 わす係数 $s_{i}$ を用いて， $\beta_{i}$ を式(5)のように修正した. これ は, 粉末度か湾化した際に, 基準発熱速度か湾化すると同 時に各鈗物単位量当りの自由水との接触面積も変化する ことを考慮したものである.

$$
\beta_{i}=1-\exp \left\{-r\left\{\left(\frac{\omega_{\text {free }}}{100 \cdot \eta_{i}{ }^{*}}\right) / s_{i} \frac{1}{2}\right\}^{s}\right\}
$$

ここで, $r, s, v$ は全ての鉱物に対して共通の材料定数 であり, 実験結果と解析結果の対応から, $r=5.0$, $s=2.4, v=1.0$ と決定した. $\omega_{\text {free }}$ は正規化された自由 水量, $\eta_{i}$ は正規化された鉱物 $i$ の内部反応生成層厚であ り，それぞれ次式により与えられる。

$$
\begin{gathered}
\omega_{\text {free }}=\frac{W_{\text {total }}-\sum W_{i}}{C} \\
\eta_{i}=1-\left(1-\frac{\bar{Q}_{i}}{\bar{Q}_{i, \infty}}\right)^{\frac{1}{3}}
\end{gathered}
$$

ここで, $W_{\text {total }}$ は単位水量, $W_{i}$ は各鉱物の反応により消 
費・固定された水量, $C$ は単位セメント量, $\bar{Q}_{i}$ は鉱物 $i$ の積算発熱量, $\bar{Q}_{i \infty}$ は鉱物 $i$ の最終発熱量である（図-1 参照)。

各反応に消費される結合水量は, 各鉱物毎の反応式から 求まる結合水率とモデルにより算出される反応率 $\left(\bar{Q}_{i} / \bar{Q}_{i \infty}\right)$ を乗ずることにより求めることができる．モデ ルで採用している反応式を以下に示す ${ }^{11)}$.

$$
\begin{gathered}
C_{3} A+6 H \rightarrow C_{3} A_{6} \\
C_{4} A F+2 C H+10 H \rightarrow C_{3} A_{6}-C_{3} F_{6} \\
2 C_{3} S+6 H \rightarrow C_{3} S_{2} H_{3}+3 C H \\
2 C_{2} S+4 H \rightarrow C_{3} S_{2} H_{3}+C H
\end{gathered}
$$

ここで, $\mathrm{C} \equiv \mathrm{CaO}, \mathrm{S} \equiv \mathrm{SiO}_{2}, \mathrm{~A} \equiv \mathrm{Al}_{2} \mathrm{O}_{3}, \mathrm{~F} \equiv \mathrm{Fe}_{2} \mathrm{O}_{3}$, $\mathrm{H} \equiv \mathrm{H}_{2} \mathrm{O}, \mathrm{CH} \equiv \mathrm{Ca}(\mathrm{OH})_{2}$ である. また，式(8)で規定 される化学的に結合される水の他に, 生成された組織表面 に物理的に拘束される水として, 反応する全鉱物に対して 一律に 15\%の拘束水率を仮定し，式(6)で用いている.

ポルトランドセメントの水和発熱モデルにおいては, ク リンカー鉱物の反応は, 反応㳯が 100\%に達するか, もし くは自由水の減少による発熱速度の低隇によってのみ終 了する. しかし, 混合セメントの場合には, 水酸化カルシ ウムの不足によって, 自由水量は十分であるにもかかわら ず, 高炉スラグやフライアッシュの反応速度が減少するこ とがある. 仮に, 水酸化カルシウムが不足することで, 混 和材の反応が停滞したとすると, 残存している自由水量は ポルトランドセメントの水和反忍に対して, 反応を起こす 対象もしくは水和生成物の析出空間として有効に機能す るものと考えられる。 そこで, 混和材の反応が水酸化カル シウムの不足により停滞した場合の, ポルトランドセメン トに対する自由水の減少の影響を, 式(6)を修正して次式に より評価することとした。

$$
\begin{gathered}
\omega_{\text {free }}=\frac{W_{\text {total }}-\sum W_{i}}{C \cdot\left(p_{P C}+m_{S G} \cdot p_{S G}+m_{F A} \cdot p_{F A}\right)} \\
m_{i}=\lambda / \beta_{i}
\end{gathered}
$$

\section{b)鉱物組成の相違による発熱速度の変化}

複合水和発熱モデルでは, 鉱物反応同士は顕著な相互依 存の関係にあり, ポルトランドセメント中の構成鉱物の比 率か湾われば各鉱物の発熱速度は变化すると考え, 係数 $\mu$ を導入している. 構成鉱物組成の相違に応じて各鉱物の発 熱速度が変化する理由については現在のところ定かでは ない. 鉱物組成の変化が発熱速度に影響を及ぼす一因とし て, $\mathrm{Ca}(\mathrm{OH})_{2}$ 濃度の変化に伴う $\mathrm{pH}$ の変化や粒子近傍にお ける他のイオン濃度の相違などが考えられる. 特に粒子近 傍の液相に着目すれば, ポルトランドセメントの鉱物組成 か湾化すると, あるセメント粒子に隣接する $\mathrm{C}_{3} \mathrm{~S}$ と $\mathrm{C}_{2} \mathrm{~S}$ の存在確率は相対的に変化し, $\mathrm{pH}$ もしくは種々のイオン 濃度に代表される粒了近傍の反応環境か湾化する。しかし,
クリンカー鉱物相互の反応依存性については未だ不明な 部分が多く, また現段階では, 考え得る要因と影響の程度 との定量的な評価も困難である. そこで当面は，ポルトラ ンドセメントの鉱物組成並びに発熱特性を代表すると考 えられる $\mathrm{C}_{3} \mathrm{~S} / \mathrm{C}_{2} \mathrm{~S}$ 比を用いて単純に表わすこととし, $\mathrm{C}_{2} \mathrm{~S}$ の組成比率が高いものほど低減程度が大きくなり, 逆 に $\mathrm{C}_{3} \mathrm{~S} / \mathrm{C} 2 \mathrm{~S}$ 比が普通ポルトランドセメントに扔ける值よ りも大きければ速度か割り増される関数形を採用した ${ }^{41}$. これまで, 係数 $\mu$ は全てのクリンカー鉱物に対して考虑し たが，ここでは $\mathrm{C}_{3} \mathrm{~S}$ 及び $\mathrm{C} 2 \mathrm{~S}$ による相互依存性と考える こととし， $\mathrm{C}_{3} \mathrm{~A}$ 及び $\mathrm{C}_{4} \mathrm{AF}$ には考慮しないこととする。 た，モデルの適用範囲を早強から超低発熱ポルトランドセ メントまで拡張するのに伴い， $\mu$ を次式のように修正した。

$$
\mu=1.4 \cdot\left\{1-\exp \left(-0.48 \cdot\left(\frac{p_{C_{3} S}}{p_{C_{2} S}}\right)^{1.4}\right)\right\}+0.1
$$

一方， $\mathrm{C} 3 \mathrm{~S}$ および $\mathrm{C}_{3} \mathrm{~S}$ の stage3 以外における基準発熱 速度は，セメントの鉱物組成か湾化しても，一定であると 仮定している $(\mu=1)$ ．これは, stage2に扩る発熱速 度を組成に応じて変化させなくとも，本検討の範囲内にお いては, 初期の断熱温度履歴を比較的精度良く再現できる こと，および stage2 では，誘導期において既に溶出して いるイオンからの析出反応の影響が卓越すると仮定した ことによる. 現在のところ, 鉱物組成の変化に起因する鉱 物反応間の相互依存性については, 式(11)で簡単に扱って いるが, 今後検討を深めていく必要があると認識している. c) ポルトランドセメントより生成される水酸化カルシウ

\section{么量に依存する混和材の反応速度の評価}

Santhikumar は，コンダクションカロリメータを用い て, 高炉スラグの置換率を種々に変化させた混合セメント の水和発熱速度を測定し, ポルトランドセメントとスラグ の反応の相互依存性について詳細に検討している12) 。す なわち, 混合セメント中のポルトランドセメントの反応が 高炉スラグの影響を受けないと仮定した上で, ポルトラン ドセメント単体の発熱速度をもとに, 混合セメントの水和 発熱速度から構成比率に応じたポルトランドセメント分 の発熱速度を差し引き, 各置換率におけるスラグの発熱速 度を抽出し検討を行った. その結果, $\mathrm{Ca}(\mathrm{OH})_{2}$ の供給が十 分であると考えられる反応過程前期においては, スラグの 反応力様々な置換率においても安定しているのに対して, 反応後期においては, ポルトランドセメント含有率の相違 に応じて, 供給される $\mathrm{Ca}(\mathrm{OH})_{2}$ 量が少ないスラグ高置換 のものほど，スラグの発熱量が低减することを明らかにし ている. 反応性に乏しいフライアッシュの発熱量について は，定量的な検討は困難であるが，定性的には $\mathrm{Ca}(\mathrm{OH})_{2}$ 量に関して高炉スラグと同様のメカニズムが存在するも のと考えられる.したがって，混合セメント中の高炉スラ 
グ及びフライアッシュの発熱反応過程を適切に評価する ためには, $\mathrm{Ca}(\mathrm{OH})_{2}$ 量に着目した相互依存性の評価が不可 欠である ${ }^{13}$.

3成分系の混合セメントにおいては, 高炉スラグとフラ イアッシュの両者により $\mathrm{Ca}(\mathrm{OH})_{2}$ が消費されていくため, ポルトランドセメントからの生成量と併せて, スラグおよ びフライアッシュによる消費を経時的に算定する必要が ある. そして, 本研究では, 水酸化カルシウムが不足する ことによる混和材の反応速度の低減程度は, 系に残存する 水酸化カルシウム量と当該時点にスラグとフライアッシ 工が十分に反応するために必要とする水酸化カルシウム 量との比によって表現できるものと仮定し，式(12)により 簡便に表現している.

$$
\lambda=1-\exp \left\{-2.0 \cdot\left(\frac{F_{C H}}{R_{S G C H}+R_{F A C H}}\right)^{5.0}\right\}
$$

ここで, $F_{C H}$ は $\mathrm{C}_{3} \mathrm{~S}$ 及び $\mathrm{C}_{2} \mathrm{~S}$ の水和反応により生成 され，未だポゾランもしくは $\mathrm{C}_{4} \mathrm{AF}$ の反応に消費さ れていない $\mathrm{Ca}(\mathrm{OH})_{2}$ 量, $R_{S G C H}$ および $R_{F A C H}$ は $\mathrm{Ca}(\mathrm{OH})_{2}$ が十分に存在する場合に, 高炉スラグ及び フライアッシュの反応に必要な $\mathrm{Ca}(\mathrm{OH})_{2}$ 量である.

高炉スラグ及びフライアッシュの単位反応量当りの $\mathrm{Ca}(\mathrm{OH})_{2}$ の消費率を仮定すれば, $F_{C H}$ は本モデルにおい て採用した化学反応式により決まる $\mathrm{Ca}(\mathrm{OH})_{2}$ の生成及び 消費率と各鉱物の反応率から求められる。一方, $R_{S G C H}$ および $R_{F A C H}$ は，高炬スラグ及びフライアッシュによる $\mathrm{Ca}(\mathrm{OH})_{2}$ 消費率と $\mathrm{Ca}(\mathrm{OH})_{2}$ が十分に存在する場合に おけるそれぞれの反応速度によって求められる。

高炉スラグ及びフライアッシュが単位反応量当りどれ だけの $\mathrm{Ca}(\mathrm{OH})_{2}$ を消費するかについては定かではなく， 供給される $\mathrm{Ca}(\mathrm{OH})_{2}$ 量や混和材自体のキャラクターによ り, 生成物の $\mathrm{Ca} / \mathrm{Si}$ 比も変化するといわれている ${ }^{5)}$. しか しここでは, $\mathrm{Ca}(\mathrm{OH})_{2}$ 消費率は, 混和材のキャラクター によらず, 且つ全反応過程を通して一定值をとるものと仮 定し，それぞれの值は定性的な知見を基に解析を通して決 定した. 高炉スラグは, 注水直後に粒子表面に不透過膜を 形成するために, 以後の反応は抑制されると説明される ${ }^{5)}$. そして，スラグが活発な水和を持続するためには，スラグ 自身から溶離する $\mathrm{OH}$ イインン゙けでは不足であり, 外部か らの供給が必要である. しかし一般に, 普通ポルトランド セメントに対して, 高炉スラグを 60 70\%程度まで置換し ても, 断熱温度上昇試験における最終の温度上昇量はほと んと変化しないことから，60７0\%程度の置換率であれば 高炬スラグにとって十分な水酸化カルシウムの供給があ るものと考えられる. 一方, フライアッシュでは, ガラス 中のシリケートイオンの縮合度は大きく, 外部からの $\mathrm{OH}$ イオンの活発な刺激がなければ, 反応は進行しない ${ }^{5)}$. し たがって, フライアッシュが単位量反応した際の $\mathrm{Ca}(\mathrm{OH})_{2}$
の消費量は, スラグに比べて著しく多いものと考えられる. 実際に，高炉スラグの場合にはポルトランドセメントに対 する置換率が, 60\%から 70\%程度までは頻繁に使われるの に対して, フライアッシュの場合にはせいぜい $30 \%$ 程度ま でである. そこで, 高㶰スラグ及びフライアッシュによる $\mathrm{Ca}(\mathrm{OH})_{2}$ 消費率は，解析における検討と併せて，それぞ

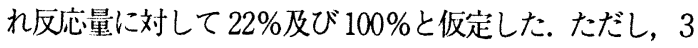
成分系の混合セメントにおいては，高炉スラグの反応がフ ライアッシュに比べて格段に早いために, 液相中の $\mathrm{Ca}(\mathrm{OH})_{2}$ は, ほとんど高炉スラグの反応によって優先的に 消費されるものと考えられる.

d) フライアッシュおよび有機混和剤による反応遅延効果

\section{の表現}

有機混和剤を添加したセメントの水和反応では, 活発な 反応の開始時期が遅延されることが知られている ${ }^{14)}$.こ れは，有機混和剤とセメントの水和により生成する $\mathrm{Ca}^{2+}$ イオンが反応して, 液相中の $\mathrm{Ca}^{2+}$ イオンが消費されること により，活発な水和発熱の開始となる $\mathrm{Ca}(\mathrm{OH})_{2}$ の結晶核 の生成が遅れたり, 結晶の生成速度が遅れるためと説明さ れる ${ }^{15)}$. ポルトランドセメントの複合水和発熱モデルで は, 有機混和剂による反応の遅延効果を一次近似として簡 略にモデル化している. また, ポルトランドセメントにフ ライアッシュを添加した場合にも反応が遅延することが 知られている5).

Santhikumar は，フライアッシュの置換率を様々に変 化させた 2 成分系の混合セメントの水和発熱速度の測定 を行い，セメントの活発な水和による発熱ピークが, フラ イアッシュの置換率の増加に応じて遅延することを示し ている ${ }^{21}$ 。また，試薬を用いた高炉スラグとフライアッ シュによる2成分系の発熱速度の検討より, フライアッシ ユは高炉スラグの反応に対してもセメントと同様に遅延 効果があることを明らかにしている12!．フライアッシュ がセメントの初期の反応を遅延させるのは, 接水と同時に 液相中に溶出した $\mathrm{Al}^{3+}$ イオンのあとに, 液相中の $\mathrm{Ca}^{2+}$ イ オンか吸着されるために, 液相中の $\mathrm{Ca}^{2+}$ イオン濃度か泜く 保たれるためと指摘されている ${ }^{5)}$. したがって, フライア ッシュの添加による反応遅延も有機混和剤の場合と同様 のメカニズムであるといえる. そこで本研究においては,

フライアッシュによるポルトランドセメント及び高炬ス ラグに対する遅延効果も有機混和剂による遅延モデルと 同様に取り扱うこととする.

これまで複合水和発熱モデルでは，遅延と無関係に消費 される有機混和凨 ${ }^{15)}$ はエトリンガイトに取り込まれるも のと考え， $\mathrm{C}_{3} \mathrm{~A} ， \mathrm{C}_{4} \mathrm{AF}$ 量および二水石膏量を用いて表現 してきた. しかし, 同時添加と後添加では著しく遅延効果

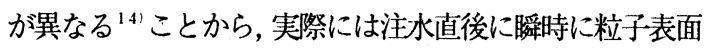
に吸着する量に相当するものと考えることとした，そこで， 
有機混和剤の一部は $\mathrm{Al}$ 分を有する $\mathrm{C}_{3} \mathrm{~A}, \mathrm{C}_{4} \mathrm{AF}$, 高炉スラ グ及びフライアッシュの粒子表面に吸着されると考え, 遅 延と無関係に消費される有機混和㓮の量を次式のように 表現することとした.

$$
\begin{array}{r}
\vartheta_{\text {Waste }}=\frac{1}{200} \cdot\left(16 p_{C_{3 A}} \cdot s_{C_{3 A}}+4 p_{C_{4 A F}} \cdot s_{C_{4 A F}}\right. \\
\left.+p_{S G} \cdot s_{S G}+5 p_{F A} \cdot s_{F A}\right)
\end{array}
$$

ここで， $\vartheta_{\text {Waste }}$ は有機混和侴の内，各鉱物の表面に吸着さ れ，遅延作用を発揮しない成分を表わす。したがって，有 機混和剤による有効遅延能力 $\vartheta_{\text {SPef }}$ は， $\vartheta$ Waste を用いて次 式で表わされる.

$$
\vartheta_{S P \text { ef }}=p_{S P} \cdot \chi_{S P}-\vartheta_{\text {Waste }}
$$

ここで, $p_{S P}$ はセメントに対する添加率 $(C \times \%)$ として 表記した混和剤添加量, $\chi_{s p}$ は有機混和剂単位量当たりの 遅延能力を表わす係数である.したがって， $p_{S P} \cdot \chi_{S P}$ は， 添加された混和剤による総遅延能力を表わす。ここで, 有 機混和剂による総遅延能力を各鉱物による吸着能力が上 回る場合には， $\vartheta_{\text {SPef }}$ は 0 とする。また，フライアッシ ユによる遅延効果は, フライアッシュの置換率に比例する として次式により表わすこととする.

$$
\vartheta_{F A \text { ef }}=0.02 p_{F A} \cdot s_{F A}
$$

一方, 有機混和剤とフライアッシュに対して $\mathrm{Ca}^{2+を}$ を提供 する鉣物として, 本研究では $\mathrm{C}_{3} \mathrm{~S}, \mathrm{C}_{2} \mathrm{~S}$ 及び高炉スラグを 取り上げた。 そして，フライアッシュ及び有機混和剤によ る発熱速度の低減を表わす係数 $\gamma$ を, フライアッシュ及び 有機混和剂による有効遅延能力と，これを相殺する $\mathrm{Ca}^{2+}$ 供給鉱物の組成量を用いて，次式のように表現した。

$$
\gamma=\exp \left\{-\frac{1000\left(\vartheta_{S P_{e f}}+\vartheta_{F A e f}\right)}{10 p_{C 3 S} \cdot s_{C 3}+5 p_{C_{2} S} \cdot s_{C_{2} S}+2.5 p_{S G} \cdot s_{S G}}\right\}
$$

提案する複合水和発熱モデルでは，遅延効果を誘導期の長 期化として取り扱い，誘導期に相当する stage 1 における 発熱速度を $\gamma$ によって低減させることにより，反応の遅延 を表現する．従来のモデルにおいては，各鉱物の stage1 において，それぞれ異なる反応速度 (発熱速度/最終発熱 量）を仮定していたために，感度解析を行い鉣物ごとの低 減率に適当な重み付けを行っていだ)。しかし, 遅延が著 しい場合には, 各鉱物の活発な反応の開始時期が大きくず れることから，各鉱物の stage1 の反応速度を同一とし， 遅延効果に応じて同一の低減率を与えるように修正した。

\section{2 成分型混合セメントの断熱温度上昇履歴に対 する検討}

鈴木は，普通ポルトランドセメントを母材とし，高炬ス ラグもしくはフライアッシュによりセメントの一部を置 換した 2 成分系混合セメントの系統的な断熱温度上昇試
表-1 断熱温度上昇試験におけるセメントの鉱物組成

\begin{tabular}{|c|c|c|c|c|c|}
\hline & $\mathrm{C}_{3} \mathrm{~A}$ & $\mathrm{C}_{4} \mathrm{AF}$ & $\mathrm{C}_{3} \mathrm{~S}$ & $\mathrm{C}_{2} \mathrm{~S}$ & $\mathrm{CS}_{2} \mathrm{H}$ \\
\hline $\mathrm{OPC}$ & 10.4 & 9.4 & 47.2 & 27.0 & 3.9 \\
\hline
\end{tabular}

注) $\mathrm{CS} 2 \mathrm{H}:$ - 水石亮

表-2 断熱温度上昇試験におけるコンクリートの配合

\begin{tabular}{|c|c|c|c|c|c|c|}
\hline & W/C & W & C & S & G & AE 減水剂 \\
\hline SG400 & 39.2 & 157 & 400 & 658 & 1129 & 0.25 \\
\hline SG300 & 49.3 & 148 & 300 & 765 & 1129 & 0.25 \\
\hline SG200 & 78.5 & 157 & 200 & 862 & 1089 & 0.25 \\
\hline FA400 & 39.2 & 157 & 400 & 663 & 1129 & 0.25 \\
\hline FA300 & 49.3 & 148 & 300 & 770 & 1129 & 0.25 \\
\hline FA200 & 78.5 & 157 & 200 & 865 & 1089 & 0.25 \\
\hline
\end{tabular}

単位) W/C:\%, W,C,S,G:kg/m $\mathrm{m}^{3}, \mathrm{AE}$ 減水剂: $\mathrm{C} \times \%$

験を実施している7゙. 実験では, 高炉スラグ混合セメント， フライアッシュ混合セメントそれぞれについて, 打込み温 度を $10^{\circ} \mathrm{C}, 20^{\circ} \mathrm{C}, 30^{\circ} \mathrm{C}$, 単位セメント量を $200 \mathrm{~kg} / \mathrm{m}^{3}$, $300 \mathrm{~kg} / \mathrm{m}^{3}, 400 \mathrm{~kg} / \mathrm{m}^{3}$ の 3段階に変化させている(SG200, SG300, SG400, FA200, FA300, FA400). 使用された母材 セメントの鉱物組成を表-1 に，コンクリートの配合を表2 に示す．混和剤による遅延モデルの修正に伴い，遅延型 の $\mathrm{AE}$ 減水剂の単位量当たりの遅延能力を, $\chi_{S P}=5.0$ と して解析を行った。 なお，全ての解析における時間差分間 隔は, 水和開始後 0.3 日までは 0.01 日であり, 以降は 0.05 日としている. 複合水和発熱モデルの普通ポルトランドセ メント及び中庸熱ポルトランドセメントに対する適用性 については既に検証済みであり，早強ポルトランドセメン トについても適用できることを確認している (図一7参照). 実験結果および解析結果を図-4 および図-5に示す。

本研究で仮定した高炉スラグおよびフライアッシュの 発熱特性值は，この実験結果を再現するように設定した。 各打込み温度において反応の温度依存性を反映して, ほぼ 断熱温度上昇履歴を再現している. ただし，フライアッシ ユ混合セメントにおいて，打設温度が $10^{\circ} \mathrm{C}$ 場合の適合 性か悪く, 現状のモデル化では stage2 の後半以降の著し い遅延が再現できていない. 解析によれば, この部分の温 度上昇は, 主としてポルトランドセメントの発熱によって もたらされており, フライアッシュの基準発熱速度の設定 とは関係がないものと考えられる. 本モデルにおいては, stage1 以外における有機混和剂拉よびフライアッシュの 影響を考慮していないことや混和郕による遅延効果とフ ライアッシュによる遅延効果との相乗作用等が原因とし て考えられるが, 併せて遅延効果の温度依存性についても 検討を行う必要があると考えられる，また，実験で使用さ 

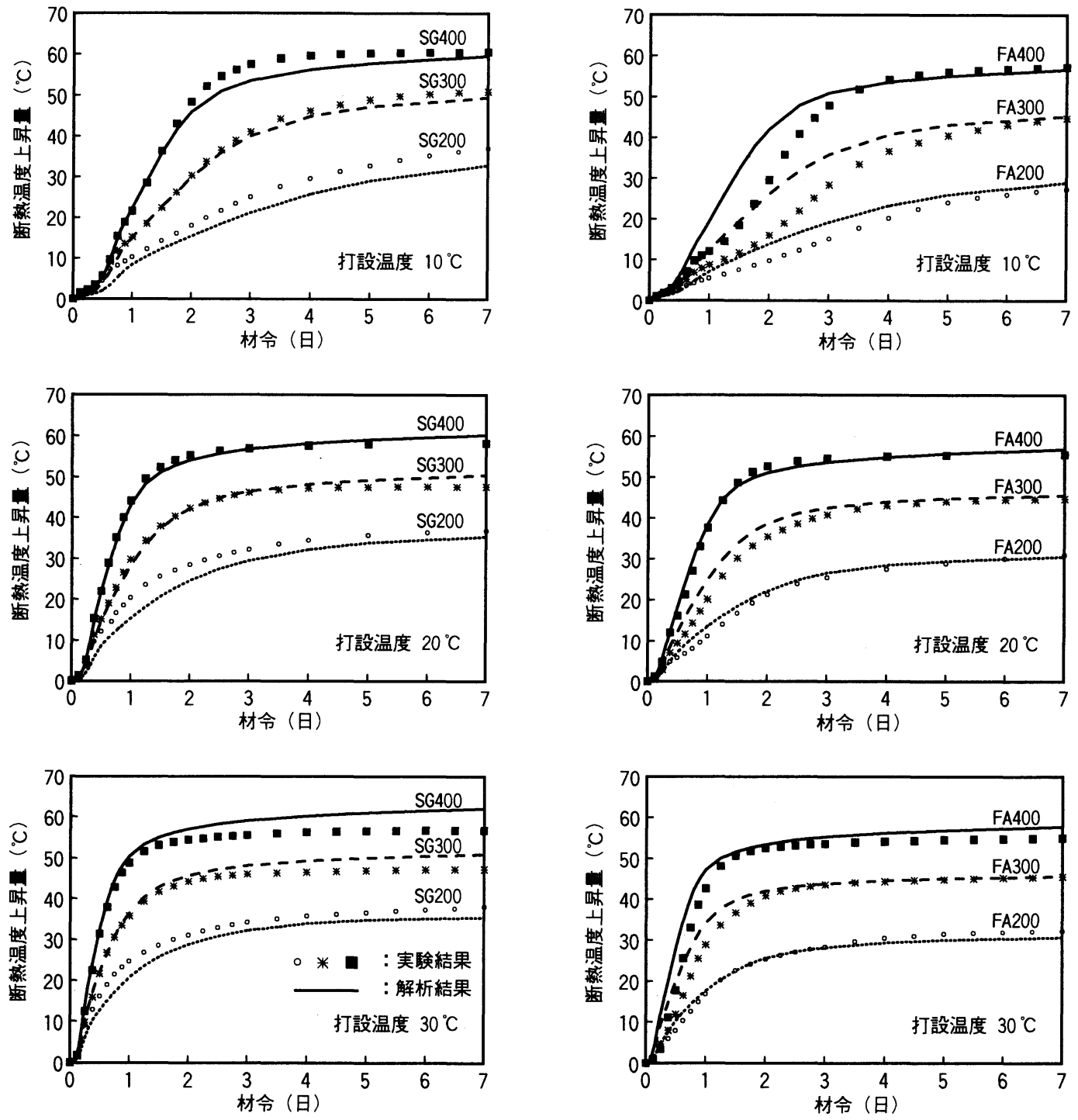

図-4 断熱温度上昇履歴に対する解析結果 （高炬スラグ $40 \%$ 置換）

れた遅延型の $\mathrm{AE}$ 隇水剤の特性についても適切なモデル化 を行う必要がある. 高炬スラグ及びフライアッシュの消費 水率は，2成分系における本解析を通して，それぞれ $30 \%$ ， $10 \%$ と仮定した. 単位セメント量が $400 \mathrm{~kg}$ の場合には, 水セメント比が $40 \%$ と低いことによる水和発熱速度への 影響を考虑したことにより，反応末期の速度低減及び断熱 温度上昇量の低下が再現されている。 また, 練り混ぜ開始 から打設までの主としてエトリンガイトの生成反応に伴 う発熱量の逸散を考虑したことにより, 異なる打設温度に おける最終温度上昇量が同程度となっているが, 打設温度 が高い場合ほど最終温度上昇量が小さくなるという実験

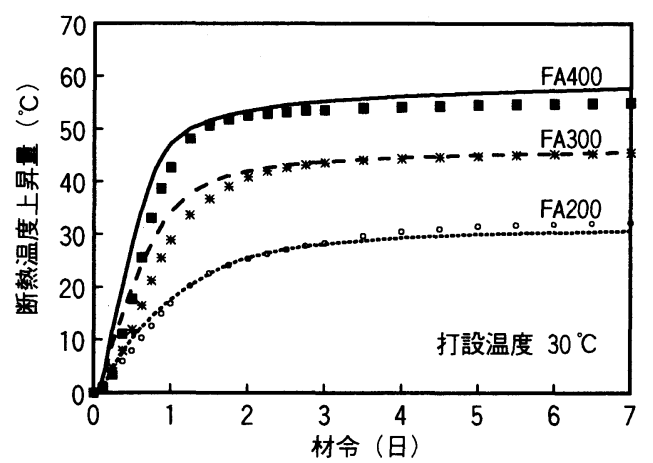

図-5 断熱温度上昇履歴に対する解析結果 (フライアッシュ $20 \%$ 置換)

結果を完全に再現するまでには至っていない。

\section{4. 擬似断熱温度上昇実験による検証}

\section{(1)実験の概要}

提案する水和発熱モデルの適用性，およびモデルにおい て設定している各材料特性値の検証を行うために, 既往の 研究 ${ }^{4)}$ に扔いて，厚さ $8 \mathrm{~cm}$ の発泡スチロールで全面を被 覆したコンクリートブロックの中心部分における温度計 測実験を行っている.ここでは，モデルの広範な適用性を 確認するために早強抢よび超低発熱ポルトランドセメン 
表-3 擬似断熱温度上昇試験に用いた母材セメントの鉱物組成

\begin{tabular}{|c|c|c|c|c|c|c|}
\hline & $\mathrm{C}_{3} \mathrm{~A}$ & $\mathrm{C}_{4} \mathrm{AF}$ & $\mathrm{C}_{3} \mathrm{~S}$ & $\mathrm{C}_{2} \mathrm{~S}$ & $\mathrm{CS}_{2} \mathrm{H}$ & ブレーン值 \\
\hline $\mathrm{EPC}$ & 9.1 & 7.9 & 61.5 & 13.0 & 6.5 & $(4210)$ \\
\hline $\mathrm{OPC}$ & 10.4 & 7.9 & 49.9 & 24.7 & 4.5 & $(3380)$ \\
\hline $\mathrm{MC}$ & 2.9 & 12.5 & 49.5 & 28.7 & 4.1 & 3240 \\
\hline $\mathrm{BC}$ & 2.5 & 13.1 & 26.3 & 52.8 & 4.5 & 3040 \\
\hline $\mathrm{SBC}$ & 2 & 6 & 16 & 71 & 4.3 & 3480 \\
\hline
\end{tabular}

注） EPC：早強ポルトランドセメント, OPC：普通ポルトラン ドセメント, $\mathrm{MC}$ ：中庸熱ポルトランドセメント, $\mathrm{BC}$ : 低発 熱ポルトランドセメント, SBC：超低発熱ポルトランドセメ ント, CS2H:二水石膏, ブレーン值：ブレーン比表面積 $\left(\mathrm{cm}^{2} / \mathrm{g}\right)$, ただし( )内の数值は解析において仮定した值

表-4 擬似断熱温度上昇試験に用いたコンクリートの配合

\begin{tabular}{|c|c|c|c|c|c|c|c|}
\hline & W/C & W & C & S & G & SP & 打設温度 \\
\hline EPC & 31.9 & 174 & 545 & 857 & 827 & $1.5^{* 1)}$ & $23.5^{\circ} \mathrm{C}$ \\
\hline OPC & 31.6 & 174 & 550 & 857 & 827 & $1.5^{* 1)}$ & $23.5^{\circ} \mathrm{C}$ \\
\hline MC & 31.5 & 182 & 577 & 828 & 827 & $1.0^{* 1)}$ & $19.5^{\circ} \mathrm{C}$ \\
\hline BC & 24.3 & 185 & 761 & 722 & 798 & $\left.0.9^{*}\right)$ & $17.5^{\circ} \mathrm{C}$ \\
\hline SBC & 25.0 & 187 & 749 & 722 & 798 & $\left.0.9^{*}\right)$ & $13.1^{\circ} \mathrm{C}$ \\
\hline
\end{tabular}

単位) W/C:\%, W,C,S,G:kg/m ${ }^{3}$, 高性能 $\mathrm{AE}$ 減水剂: $\mathrm{C} \times \%$

注） SP:高性能 AE 減水剂, *1): $\beta$ ナフタレンスルホン酸系,

*2):ポリカルボン酸系

表-5 温度解析に用いた熱定数

\begin{tabular}{|l|l|}
\hline 熱伝導率 & $41 \mathrm{kcal} / \mathrm{m} \cdot$ day $\cdot{ }^{\circ} \mathrm{C}$ \\
\hline 熱伝達率 & $18 \mathrm{kcal} / \mathrm{m}^{2} \cdot$ day $\cdot{ }^{\circ} \mathrm{C}$ \\
\hline
\end{tabular}

トの実験を追加した、実験は, 室温がほほ一定温度にに保 たれた実験室内で行った。供試体の概略を図一6に示す。コ ンクリートの配合は，いずれのセメントにおいても自己充 填性コンクリートである. 使用したセメントの鉱物組成を 表-3に, コンクリートの配合を表-4に示す.

\section{(2)水和発熱モデルによる温度解析}

a) 各種ポルトランドセメントに対する検討

温度解析は, 原田らによる水和発熱過程と熱伝導の連成 を考慮した非線形有限要素解析 ${ }^{16)}$ に, 提案する水和発熱モ デルを組み込むことにより行った. 温度解析に用いた熱定 数を表-5に示す. 高性能减水剂は, 早強(EPC), 普通(OPC) および中庸熱セメント(MC)においては， $\beta$ ナフタレンス ルホン酸塩縮合物系のものを, また低発熱(BC)及び超低発 熱セメント(SBC)においては，ポリカルボン酸塩を主成分 とするものを使用しているが, 高性能減水剂の遅延

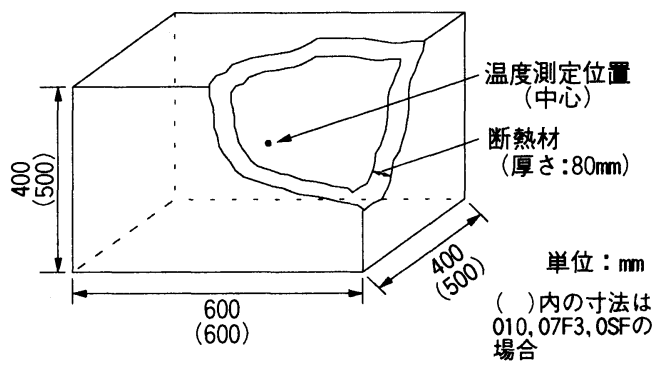

図-6 擬似断熱温度上昇供試体
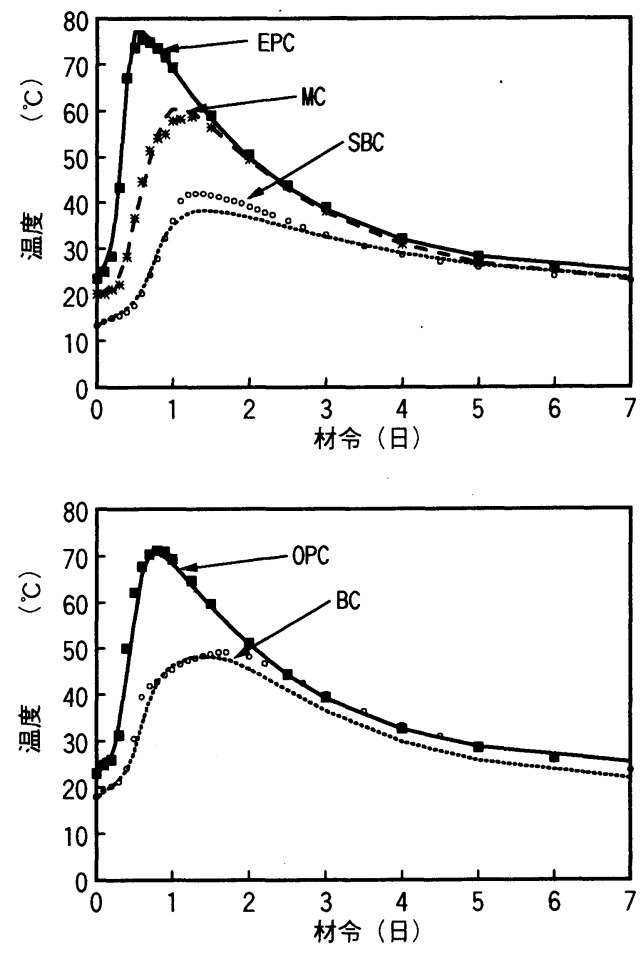

図-7 擬似断熱温度上昇試験に対する解析結果 (各種ポルトランドセメント)

能力を表わす係数 $\chi_{S P}$ には, 実験結果における急激な温度 の上昇開始時期を再現するように，それぞれ 1.2 を与えた。 実験および解析結果を図一7に示す. 早強ポルトランドセメ ント(EPC)から超低発熱ポルトランドセメント(SBC)に至 る 5 種類の各種セメントに対して, 提案する水和発熱モデ ルにより，概して実験結果を適切に再現しているといえる. ただし，低発熱および超低発熱ポルトランドセメントにお いては, ピーク温度およびピーク以降の温度降下状況を十 分には再現しておらず，主として stage3に大きく影響す 
表-6 擬似断熱温度上:昇試験に用いたセメントの鉱物組成

\begin{tabular}{|c|c|c|c|c|c|c|}
\hline & $\mathrm{C}_{3} \mathrm{~A}$ & $\mathrm{C}_{4} \mathrm{AF}$ & $\mathrm{C}_{3} \mathrm{~S}$ & $\mathrm{C}_{2} \mathrm{~S}$ & $\mathrm{CS} 2 \mathrm{H}$ & 7゙レ-ン値 \\
\hline O5S5 & 10.4 & 7.9 & 49.9 & 24.7 & 4.5 & $(3380)$ \\
\hline M6S4 & 2.9 & 12.5 & 49.5 & 28.7 & 4.1 & 3240 \\
\hline O10 & 10.3 & 8.2 & 53.7 & 19.8 & 4.3 & $(3380)$ \\
\hline O7F3 & 10.3 & 8.2 & 53.7 & 19.8 & 4.3 & $(3380)$ \\
\hline OSF & 10.3 & 8.2 & 53.7 & 19.8 & 4.3 & $(3380)$ \\
\hline
\end{tabular}

注）ブレーン值：ブレーン比表面積 $\left(\mathrm{cm}^{2} / \mathrm{g}\right)$ ，ただし( )内の数値 は解析において仮定した值

表-7 擬似断熱温度上:昇試験に用いたコンクリートの配合

\begin{tabular}{|c|c|c|c|c|c|c|c|}
\hline & $\mathrm{W} / \mathrm{C}$ & W & $\mathrm{C}$ & $S$ & G & SP & 打設温度 \\
\hline O5S5 & 32.9 & 182 & 553 & 828 & 827 & $1.1^{\star 1)}$ & $20.0^{\circ} \mathrm{C}$ \\
\hline M6S4 & 31.3 & 180 & 576 & 803 & 827 & $1.5^{\text {*d) }}$ & $16.5^{\circ} \mathrm{C}$ \\
\hline 010 & 36.0 & 180 & 500 & 757 & 902 & $0.25^{\star * 3)}$ & $25.5^{\circ} \mathrm{C}$ \\
\hline $\mathrm{O} 7 \mathrm{~F} 3$ & 36.0 & 180 & 500 & 731 & 873 & $0.25^{\star 3)}$ & $25.5^{\circ} \mathrm{C}$ \\
\hline OSF & 30.1 & 160 & 531 & 765 & 879 & $1.2^{\star 1)}$ & $25.0^{\circ} \mathrm{C}$ \\
\hline
\end{tabular}

注） O5S5 : OPC $50 \%+$ slag $50 \%$, M6S4 : MC60\%+slag $40 \%$,

O10 : OPC100\%, 07F3 : OPC70\%+fly ash $30 \%$,

OSF : OPC $30 \%+$ slag $28 \%+$ fly ash $42 \%$

*1): $\beta$ ナフタレンスルホン酸系, *2):ポリカルボン酸系,

*3): $\mathrm{AE}$ 減水剂

単位) W/C:\%, W,C,S,G:kg/m³ , 高性能 $\mathrm{AE}$ 減水剂: $\mathrm{C} \times \%$

る鉱物組成の相違による発熱速度の变化を適切に評価す ることが今後の検討課題として上げられる.

b) 2 成分系混合セメント

2 成分系混合セメントに対するモデルの適用性を確認 するために, 高炉スラグ混合セメントとして普通ポルトラ ンドセメントに高炉スラグを 50\%置換したもの (O5S5) および中庸熱ポルトランドセメントに高炉スラグを $40 \%$ 置換したもの（M6S4）の2種類の擬似断熱温度上昇実験 を行った. またフライアッシュ混合セメントとして, 普通 ポルトランドセメントにフライアッシュを $30 \%$ 置換した もの (O7F3) の擬似断熱温度上昇実験を行った，比較の ために, フライアッシュ混合セメントの母材として用いた 普通ポルトランドセメント $100 \%$ （O10）についても実験 を行った。 供試体の概略は図-6 と同様であるが, O7F3 お よび $\mathrm{O} 10$ については供試体が若干大きく, 図中の（） 内の寸法で行った. 使用した母材セメントの鉣物組成を表 ー6に,コンクリートの配合を表-7に示す.

高炉スラグ混合セメントにおいては，O5S5 および M6S4 いずれの配合においても, 温度履歴及び最高温度と も適切に再現している.ただし O5S5においては, 全体的 に 0.25 日程度早めの解析結果を与えている. これは, 実 験において, 高性能減水剤の一部を後添加したにもかかわ

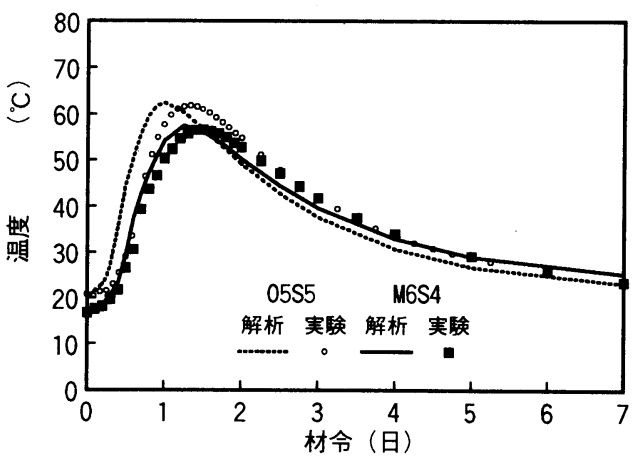

図-8 擬似断熱温度上昇試験に対する解析結果

(高炉スラグ混入 2 成分系混合セメント)

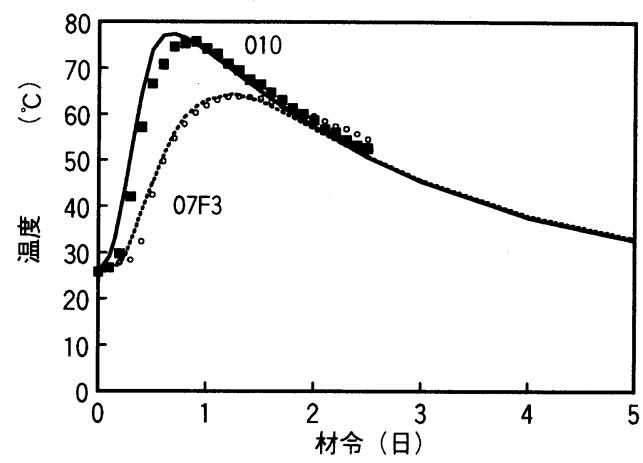

図-9 擬似断熱温度上昇試験に対する解析結果

(フライアッシュ混入 2 成分系混合セメント)

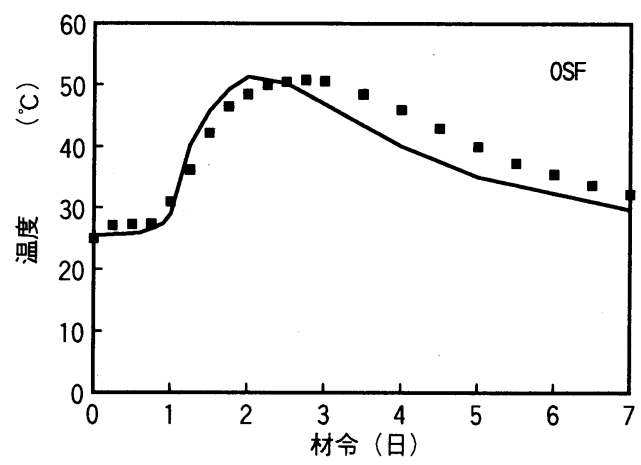

図-10 擬似断熱温度上昇試験に対する解析結果 (3 成分系混合セメント)

らず, モデルにおいては後添加の影響を適切に考慮してい ないことによると考えられる. また，フライアッシュ混合 セメントである O7F3においても，母材セメント 100\%で ある 010 と共に, ほぼ実験結果を再現している. O7F3 においては, フライアッシュの遅延効果を評価したことに より温度の上昇開始時期をおおむね再現しているが, 温度 の降下程度は実験結果に対して若干大きくなっている. 


\section{C) 3 成分系混合セメント}

高炉スラグおよびフライアッシュを含む 3 成分系混合 セメント (OSF) を用いた擬似断熱温度上昇実験を行った。 供試体の大きさは, 図一6（）内に示した寸法である. 使用した母材セメントの鉱物組成およびコンクリートの 配合は，それぞれ表-6，表-7に併せて示してある。

有機混和剂およびフライアッシュによる遅延効果をモ デル化したことにより, 温度上昇の開始時期はほぼ適切に 再現しているが, 温度上舁以降の適合性が十分とは言えな い. 配合は, 母材セメントの含有率が $30 \%$ 以下であり, 解 析においては, 高炬スラグおよびフライアッシュの反応が 水酸化カルシウムの不足により, 著しく低減されている. 一方，低水結合材比の配合であるが，高炉スラグとフライ アッシュの反応か泜减したことにより, 自由水はクリンカ 一鉱物に対して優先的に割り当てられることになり，クリ ンカー鉱物に対する $\beta_{i}$ による低减程度は緩和されている。

しかし, ピーク温度以降の緩やかな温度降下を精度良く再 現するまでには至っていない。

\section{5. まとめ}

ポルトランドセメント中の反応群を反応単位であるク リンカー鉱物毎に分解し，それぞれの反応について水和発 熱過程を記述したポルトランドセメントの複合水和発熱 モデル ${ }^{4)}$ に, 高炉スラグおよびフライアッシュの要素を組 み入れ，反応間の相互依存性を考慮した混合セメントの水 和発熱モデルを提案した. 打設以前の反応相当分の発熱量 を考慮することにより，打ち込み温度の相違による終局温 度への影響を考虑している．また，高炉スラグおよびフラ イアッシュの反応は, ポルトランドセメントの水和により 生成する水酸化カルシウム量に依存するものとなってい る. 提案した水和発熱モデルの適用性は, 断熱温度上昇試 験結果および小型の擬似断熱供試体の温度計測結果に対 する解析を通して検証され，工学的な応用に耐之得る適用 範囲の広さと精度か確認された，今後は，モデルの精度向 上を更に図ると共に, 仮定した各パラメータの值の妥当性 を検証する必要があるものと認識している.

\section{参考文献}

1) 岡村 甫, 前川宏一, 小沢一雅：ハイパフォーマンス コンクリート，技報堂出版， 1993 .

2) Kishi, T., Shimomura, T. and Maekawa, K.: Thermal crack control design of high performance concrete, Proc. of Concrete 2000, pp.447-456, Dundee, UK., 1993.

3) Kishi, T., Ozawa, K. and Maekawa, K.: Multicomponent model for hydration heat of concrete based on cement mineral compounds, Proceedings of JCI, Vol.15, No.1, pp.1211-1216, 1993.

4) 岸 利治, 前川宏一:ポルトランドセメントの複合水 和発熱モデル, 土木学会論文集, No.526/V-29, pp.97-109, 1995.

5）内川 浩:混合セメントの水和掞よび構造形成に及ぼ す混合材の効果〈その $2>$, セメント・コンクリート No.484, pp.81-93, 1987.

6) 鈴木康範，辻 幸和，前川宏一，岡村 甫：コンクリ 一ト中に存在するセメントの水和発热渦程の定量化, 土木学会論文集, No.414/V-12, pp.155-164, 1990.

7）鈴木康範：コンクリート中のセメントの水和発熱過程 と定量化に関する研究, 東京大学学位論文, 1990.

8）伊藤秀敏, 藤木洋一: 高炬スラグ微粉末を混入したコ ンクリートについて, 高炉スラグ微粉末のコンクリー トへの適用に関するシンポジウム論文集（土木学会）, pp.37-42, 1987.

9）鈴木康範，原田修輔，前川宏一，过 幸和：新試験装 置によるコンクリートの断熱温度上昇量の定量化, 土 木学会論文集, No.396/V-9, pp.109-117, 1988.

10）守分敦郎，福手 勤, 堀口浩司：マスコンクリートの 耐久性に関する検討, コンクリート工学年次論文報告 集, Vol.15, No.1, pp.859-864, 1993.

11）荒井康夫：セメントの材料化学, 大日本図書, 1984.

12) Santhikumar, S.: Temperature dependent Heat generation model for mixed cement concrete with mutual interactions among constituent minerals, The master thesis submitted to the university of Tokyo, 1993.

13) Kishi, T., and Maekawa, K.: Thermal and Mechanical Modelling of Young Concrete Based on Hydration Process of Multi-Component Cement Minerals, Proceedings of the international RILEM symposium on Thermal Cracking in Concrete at Early Ages, pp.11-18, Munich, Germany, 1994.

14）内川 浩, 沢木大介, 羽原俊祐：フレッシュセメント ペーストの流動性に及ほす有機混和剤の種類と添加 方法の影響, 超流動コンクリートに関するシンポジウ 么論文報告集（JCI），pp.55-62，1993.

15）魚本健人, 大下健二: 高性能減水剤によるコンクリー トの凝結遅延に関する基礎的研究, コンクリート工学 論文集, Vol.5/No.1, pp.119-129, 1994.

16）原田修輔，前川宏一, 辻 幸和, 岡村 甫: 温度依存 性を有するセメントの水和発熱過程と熱伝導との連 成を考慮した非線形温度解析, 土木学会論文集,

No.426/V-14, pp.167-176, 1991. 


\section{MULTI-COMPONENT MODEL FOR HYDRATION HEAT OF BLENDED CEMENT WITH BLAST SLAG AND FLY ASH}

\section{Toshiharu KISHI and Koichi MAEKAWA}

This study is to propose the multi-component model for hydration heat of blended cement. The hydration degree of each mineral compound of Portland cement as well as the pozzolans is computed step by step with modified Arrhenius's law of chemical reaction. The chemical interactions among mineral compounds of Portland cement and pozzolans are taken into account in terms of the specific free water and the amount of calcium hydroxide assigned as state variables representing chemical environment of pore solution. The proposed model was verified through the analyses of the adiabatic and semi-adiabatic temperature rises. 